\title{
FILOSOFIA DA EDUCAÇÃO: A OPOSIÇÃO ENTRE ANALÍTICOS E CONTINENTAIS
}

\author{
Amador C. Batista Filho ${ }^{1}$ \\ Alvaro Emídio Ferreira ${ }^{2}$
}

\begin{abstract}
Resumo:
O presente texto analisa a oposição bastante conhecida no século XX, entre os filósofos analíticos e continentais no campo da Educação. Assim, inicialmente é esclarecido de modo breve "o que é a filosofia" e também qual a natureza peculiar da filosofia da educação. Na sequência, se compara as tendências fundamentais da filosofia da educação. Para tanto, a obra de Bagdan Suchodolski é confrontada com a revolução romântica e que está na base oposição entre os filósofos analíticos e continentais. Finalmente, a separação "geográfica" e "cultural" que está na origem do pensamento filosófico contemporâneo é ampliada com o propósito de incluir as querelas pósmodernistas no campo da Educação.
\end{abstract}

Palavras-chave: Analíticos e Continentais, Iluminismo, Pós-Modernidade.

\section{PHILOSOPHY OF EDUCATION: THE OPPOSITION BETWEEN ANALITICS AND CONTINENTAL}

\begin{abstract}
:
This text analyzes the well-known opposition in the 20th century between analytical and continental philosophers in the field of Education. Thus, initially is briefly clarified "what philosophy is" and also what is the peculiar nature of the philosophy of Education. Next, the fundamental trends in the philosophy of education are compared. Therefore, the work of Bagdan Suchodolski is confronted with the romantic revolution, wich is the base opposition between analytic and continental philosophers. Finally, the "geographic" and "cultural" separations that is at the origin of including postmodernist quarrels in the field of Education.
\end{abstract}

Keywords: Analytics and continental, Enlightment, Post-Modernity.

\section{Introdução}

Os pós-modernistas exibem seu relativismo como um tipo superior de humildade - a modesta aceitação de que não podemos pretender ter a verdade. Na realidade, a negação pós-moderna da verdade é o pior tipo de arrogância. Ao negar que o mundo natural existe independentemente de nossas crenças sobre ele, os pós-modernistas estão implicitamente rejeitando qualquer limite às ambições humanas. Ao tornar as crenças humanas o árbitro final da realidade, estão efetivamente afirmando que nada existe, a menos que pareça na consciência humana (GRAY, 2007, p. 71)

\footnotetext{
${ }^{1}$ Doutor em Educação Física pela UEL. Trabalha na Secretaria da Educação do Paraná. Membro do GP Filosofia, educação e condição humana. E-mail soriani@ sercomtel.com.br.

2 Mestre em Ciências da Comunicação pela USP. Professor da universidade Norte do Paraná. E-mail: ferreira.alvaro@gmail.com
} 
O presente artigo versa sobre o contraste entre filosofia analítica e filosofia continental. Trata-se de uma questão ainda pouco discutida no domínio do pensamento filosófico da educação. Isso aponta para a longa controvérsia filosófica que colocou o racionalismo dogmático de um lado e o empirismo crítico de outro lado. No decurso do século XVIII, a partir da revolução romântica, a controvérsia envolvendo os representantes dos dois campos assumiu a sua forma mais extremada. Tal é a questão enfrentada nesse trabalho. De maneira muito especial, como se verá adiante, de suas implicações no panorama atual da filosofia da educação. Assim, inicialmente é esclarecido de modo breve "o que é a filosofia" e também qual a natureza peculiar da filosofia da educação. Na sequência, se compara as tendências fundamentais da filosofia da educação. Para tanto, a obra de Bagdan Suchodolski é confrontada com a revolução romântica e que está na base oposição entre os filósofos analíticos e continentais. Finalmente, a separação "geográfica" e "cultural" que está na origem do pensamento filosófico contemporâneo é ampliada com o propósito de incluir as querelas pósmodernistas no campo da Educação.

\section{Filosofia da educação: um olhar preliminar}

Ao examinar as teorias formuladas pelos primeiros cientistas-filósofos gregos, Aristóteles propôs pioneiramente que eram cosmólogos por colocarem questões relacionadas a natureza, o universo ou a ordem do mundo (POPPER, 2014). Questão que não cessou de fecundar a imaginação dos seres humanos desde os primórdios dos tempos. Portanto, a história da cosmologia é tão antiga quanto a história da humanidade. De fato, bem antes dos cientistasfilósofos gregos, os povos primitivos já se voltavam para essa questão. Daí nasce os mitos. Em geral, os mitos são considerados como narrativas acerca da origem e natureza do universo e do homem (ELIADE, 1986). Há maioria dos historiadores concordam que até o início do século XIX, a ciência e a filosofia estavam muito próximas por excluírem quaisquer fronteiras disciplinares bem delimitadas (ZIMAN, 1982). A partir disto, fica claro que a falta de um critério de demarcação preciso entre ciência e filosofia, eram efetivamente indistinguíveis (POPPER, 1982). Assim, o importante a notar no caso da ciência e da filosofia é o de encontrar o seu traço peculiar. Popper observou que:

O que é novo na filosofia grega, o que é acrescentado de novo a tudo isto, parece consistir não tanto na substituição dos mitos por algo de mais ‘científico’ quanto numa 
nova atitude para com os mitos. Parece-me ser meramente uma consequência desta nova atitude o fato de que seu caráter começa então a mudar.

A nova atitude que tenho em mente é a atitude crítica. Em lugar de uma transmissão dogmática da doutrina (na qual todo o interesse reside em preservar a tradição autêntica) encontramos uma discussão crítica da doutrina. Algumas pessoas começam a fazer perguntas a seu respeito; duvidam da veracidade da doutrina; de sua verdade.

A dúvida e a crítica existiram certamente antes deste estágio. O que é novo, porém, é que a dúvida e a crítica se tornaram agora, por sua vez, partes da tradição da escola. Uma tradição de ordem superior substitui a preservação tradicional - em lugar do mito - encontramos a tradição de teorias que criticam (as quais em si mesmas, a princípio pouco mais são do que mitos). É só no decorrer desta discussão que a observação é convocada como uma testemunha.

Mal pode ser por mero acidente que Anaximandro, discípulo de Tales, desenvolveu uma teoria que diverge explícita e conscientemente da de seu mestre, e que Anaxímenes, discípulo de Anaximandro, tenha divergido de modo igualmente consciente da doutrina de seu mestre. A única explicação parece ser a de que o fundador da escola, ele próprio tenha desafiado seus discípulos a criticarem sua teoria e que eles hajam transformado esta nova atitude crítica de seu mestre numa nova tradição (POPPER, 1975, p.319-320).

No texto $O$ Mito da estrutura, Popper traz à tona novamente a discussão sobre tal ponto. Ou seja, o que distanciava a ciência e a filosofia do mito? Diz ele, "Tenho tentado explicar este fato pela hipótese de que Thales e Anaximandro, juntos, fundaram uma nova tradição - a tradição crítica" (POPPER, 1980). Certamente porque a ciência e a filosofia são, antes de tudo, as mais genuínas expressões do modo de pensar crítico. E o pensamento constitui sempre em enxergar o erro aonde aparecer e o mais rapidamente possível (LIPMANN, 1995). Contudo, há mais. Depois de institucionalizado, essa nova forma de pensar se fez presente em uma tradição. Conforme Popper procurou demonstrar muito adequadamente, trata-se de uma Tradição Crítica. É preciso reconhecer também que sem discussão crítica ou crítica intersubjetiva os gregos jamais teriam criado teorias. Razão de John Searle conferir aos gregos o grande feito de elaborarem a ideia de teoria (SEARLE, 1999). Na verdade, plausivelmente, o que era chamado de ideia na literatura filosófica, é agora, com base na revolução cognitiva, visto como "representação". De fato, na concepção de Howard Gardner, um cientista cognitivo com uma obra consistente sobre as capacidades mentais dos seres humanos, o termo "ideia" é usado "para denotar algum conteúdo mental” (GARDNER, 2005). Em relação à representação, os cientistas cognitivos querem dizer quando falam disso é para enfatizar os conteúdos mentais

\begin{tabular}{|l|l|l|l|l|}
\hline Qovista Dialeatus & Ano 10 & n. 22 & Edição Especial, junho 2021 & p. 237 - 255 \\
\hline
\end{tabular}


que os indivíduos tem dentro da cabeça - no seu cérebro, como imagens, crenças, palavras, teorias e habilidades (GARDNER, 2005).

Entretanto, apenas na ciência e na filosofia é dado ênfase na construção de teorias. De acordo com Searle, as teorias são "construções intelectuais sistemáticas que foram concebidas para descrever e explicar vastas áreas da realidade de uma maneira lógica [experimental] e matematicamente acessível" (SEARLE, 1999, p.4). Abstraído a diferenças em torno das questões diretamente ligadas à filosofia da ciência, tanto Karl Popper quanto Larry Laudan compartilham da visão de que as teorias são construções intelectuais de um tipo bem específico. Para Popper e Laudan, as teorias são tentativas de solução de problemas acerca do mundo natural (POPPER, 1975; LAUDAN, 2011). Por isso, sem teorias, haveria um avanço bastante limitado do conhecimento científico. Posteriormente, Popper compreendeu os produtos da mente humana como uma realidade diferente, porém, ligada, de algum modo, à parte pertencente às entidades físicas e mentais. Na realidade dividida em três partes, ou Mundo 1, Mundo 2 e Mundo 3, Popper compreende as teorias como entidades pertencentes à última por serem formuladas em palavras. À primeira vista, a formulação das teorias em palavras parece trivial, mas não é. O caráter público da linguagem humana permite que as teorias sejam submetidas à discussão crítica ou à crítica intersubjetiva (Popper, 1980). Isso porque elas são fundamentais para a compreensão do mundo, pois a compreensão se dá pela solução de problemas. Por outro lado, foram os gregos que criaram a palavra e entendiam por teoria nada mais do que contemplar ou ver (FULLAT, 1995). Não resta nenhuma dúvida de que o emprego dela por Popper é muito próximo. Popper fala de teoria como uma espécie de rede lançada para formar um modelo conjectural do mundo real (POPPER, 1980).

Quanto à teorização educacional, não se pode esquecer que costuma ser alinhada no domínio das ciências da educação e da filosofia da educação. Antes de mais, a teorização educacional passou por grandes mudanças, a partir da consolidação das ciências da educação (MIALARET, 2013). Desde o início do século XX, a investigação científica em curso na Psicologia Educacional e na Sociologia da Educação teve grande importância por levar ao completo desenvolvimento das ciências da educação. Trata-se de um esforço interdisciplinar semelhante ao das ciências cognitivas e cujo objetivo é, sobretudo, o de encontrar as melhores soluções para os problemas da educação.

A filosofia da educação tem raízes na Grécia e remonta à época do aparecimento da democracia. Há que se levar em conta, por exemplo, a discussão crítica sobre os temas 
educacionais efetuada pelos sofistas e por Sócrates no século V a.C., na cidade de Atenas. Historicamente, a filosofia da educação consagrada e com mais penetração ao longo do tempo foi a de Platão e notadamente por causa de sua influente filosofia política.

A filosofia da educação gira em torno do processo educacional e constitui um ramo especial da filosofia. A filosofia da educação assegura a partir da ótica dos ramos da filosofia tais como a ontologia, a epistemologia, a lógica e a ética um tipo de teorização peculiarmente diferente da encontrada nas ciências da educação. Afinal, as teorias conectadas com a filosofia da educação permanecem fora do terreno da refutação estritamente experimental.

\section{As correntes teóricas fundamentais da filosofia da educação}

Em seu aclamado livro A pedagogia e as grandes correntes filosóficas, Bogdan Suchodolski identificou, na história da pedagogia, duas linhas teóricas bem distintas. Nelas são distinguidas a pedagogia da essência e a pedagogia da existência. Em última análise, no que respeita a filosofia da essência, se encontra em seu âmago os pressupostos teóricos que Platão formulou.

Quando jovem, Platão foi um dedicado discípulo de Sócrates. Em 399 a.C., aos setenta anos de idade, Sócrates é julgado, preso e condenado à morte. A morte trágica de Sócrates é um acontecimento carregado de significado para Platão e outros de seus discípulos e amigos. Desencantado com a carreira política, Platão volta-se para filosofia. Nos diálogos platônicos, especialmente aqueles que integram o grupo do período da primeira fase, Sócrates é o porta-voz da discussão a respeito, em grande medida, dos temas morais. Em 387 a.C. Platão funda a Academia, que servirá de protótipo às futuras universidades. O objetivo da Academia era o de formar a elite governante do Estado e dos governados. Se junta ao efeito chocante da execução de Sócrates, a crise da vida política da democracia ateniense. Portanto, a filosofia política elaborada por Platão, e que se tornou referência fundamental nos séculos subsequentes entre os maiores pensadores de todos os tempos é posterior a grandeza da democracia ateniense.

A república é a obra em que Platão elabora sua visão política do filósofogovernante. Nem é preciso dizer que Estado ideal de Platão nada tinha de comum com a democracia ateniense. Em pormenor, o seu Estado ideal é fundado em uma aristocracia brotada da educação filosófica em detrimento da determinada pelo nascimento. Ora, é fácil perceber que rei-filósofo de Platão é carente da humildade intelectual e da autocrítica que Sócrates advogava aos dirigentes e cidadãos atenienses. De resto, os indivíduos estavam subordinados a 
sociedade. A educação dos governantes era longa e levava ao conhecimento da realidade essencial (OZMON \& CRAVER, 2004).

À medida que o essencialismo torna-se parte dos letrados e eruditos religiosos do clero cristão, a ênfase é um tanto maior no corpo de conhecimentos que perdura em todas as sociedades e em todas as épocas. Dessa forma, o perenialismo é a filosofia da educação fiel aos dogmas do cristianismo. Propriamente dito, trata-se da filosofia que procura conciliar o essencialismo platônico a religião cristã.

Suchodolski, porém, fala do existencialismo como o resultado de um curioso entrelaçamento com a Renascença. Essa abordagem admiravelmente ampla parece ignorar a batalha entre os iluministas e os românticos na filosofia da educação. O legado do Romantismo é a invenção do gênio artístico iluminado que se rebela contra a sociedade surgida da Revolução Industrial. Jean J. Rousseau já contestara os pretensos progressos da civilização ocidental, em especial, na primeira metade do século XVIII. Em contraste com seus contemporâneos iluministas, Rousseau preconizava a corrupção da sociedade. E mais, ao invés do modo de pensar crítico, dá primazia as paixões. Na Alemanha, tudo isso muda. O Iluminismo torna-se inoperante. O progresso concernente ao conhecimento científico e a liberdade individual, a 242 crítica sistemática das tradições herdadas, da ignorância, da superstição, da autoridade sacerdotal e do despotismo nunca entrou na ordem do dia como fizera na Inglaterra, nos Estados Unidos e na França. A dissonância é sublinhada na oposição ao cosmopolitismo ou universalismo feita por Johann G. Herder. Em 1764, Herder louvou os valores, os costumes e a linguagem de cada povo. Posteriormente, a Alemanha arrebatada pela Revolução Francesa vai empurrar o nacionalismo cultural defendido por Herder para o nacionalismo político. Tal é a ótica de Johann G. Fichte após o exército de Napoleão Bonaparte invadir o território dos vários principados que constituirão a Alemanha. Assim, o antagonismo do Iluminismo e do Romantismo emerge da particularidade do pensamento filosófico que vai de Herder aos pósmodernistas. Isaiah Berlin é o historiador das ideias que não encontra equivalente na compreensão da revolução romântica. De acordo com Berlin,

[...] nada tão revolucionário ocorreu depois - teve lugar próximo ao final do século XVIII, principalmente na Alemanha; e embora seja bem conhecido sob o nome de 'romantismo', seu significado e importância plenos não foram apreciados até agora. Gostaria de expor minha tese em sua forma mais simples - simples demais para ser acurada e justa. É a seguinte: que o século XVIII assistiu a destruição da noção de verdade e de validade na ética e na política, não meramente da verdade objetiva ou absoluta, mas da verdade subjetiva e relativa também - verdade e validade como tal

\begin{tabular}{|l|l|l|l|l|}
\hline Qovista Oialectus & Ano 10 & n. 22 & Edição Especial, junho 2021 & p. 237 - 255
\end{tabular}


-, com resultados vastos e certamente incalculáveis. O movimento que chamamos romantismo transformou a ética e a política modernas de uma maneira muito mais séria do que nós compreendemos (BERLIN, 1999, p.237).

Parece suficientemente claro que a revolução romântica deslocou a herança filosófica elaborada na Grécia, que através dos séculos definiu a civilização ocidental. De fato, a filosofia que predominou no mundo ocidental até o Iluminismo, no seu conjunto, estava baseada na procura pela verdade. Em virtude de deixar de fazer qualquer sentido à busca da verdade entre os românticos, passa a haver aí um desvio abissal no modo de compreender a filosofia. Pode-se dizer que não há mais lugar para o modo de compreender a filosofia preconizada pelos gregos. Recusa que vai levar à elaboração de uma antifilosofia. Aliás, a vida política grega combinava verdade com liberdade. Algo extraordinário na época. A propósito, filosofia e democracia surgem ao mesmo tempo, no século VI a.C. Cabe mencionar apenas que Tales, o primeiro cientista-filósofo grego era contemporâneo de Sólon, o grande reformador da sociedade ateniense (JAEGER, 1994). Portanto, os gregos introduziram uma ligação explícita entre a verdade e a liberdade. A busca da verdade como correspondência com a realidade se entrelaça com ideia de erro. Pelo simples motivo de que ao se negar a verdade, a ideia de erro também perde sentido. O erro pressupõe a verdade. E a verdade só pode ser relatada e reconhecida quando há liberdade, seja na arena intelectual ou política. Só quando a cultura da liberdade chega a dominar a vida de uma sociedade é que a prática da discussão crítica pode desempenhar um papel importante. Ora, a discussão crítica constitui um traço peculiar tanto da filosofia quanto da democracia. Daí, a democracia ter sido vista por John Stuart Mill como "o governo mediante a discussão" (MILL, 2018). Por isso, nada é mais perigoso para os regimes autoritários que a discussão crítica proporcionada pela democracia. Contudo, poucas pessoas entenderam o mal que a negação da verdade pode trazer a civilização ocidental. É o que põe em cena Niall Ferguson no livro Civilização: Ocidente $x$ Oriente quando lembra "que a civilização ocidental já havia decaído e sucumbido antes" (FERGUSON, 2012, p.41). Com isso, ele quer dizer que a ordem política sobre a qual se funda a civilização ocidental pode sempre declinar. O ofício de Ferguson é o de historiador. Motivo de falar de acontecimentos que as pessoas já esqueceram ou sequer se dão mais conta delas. Para os historiadores do século XX, a catástrofe da Segunda Guerra Mundial constitui um dos pontos críticos da civilização ocidental já observado por conta da conexão da entre a mentira e o totalitarismo. As mentiras monstruosas cuidadosamente produzidas pelos regimes totalitários quase provocou o 
desaparecimento da civilização ocidental. o historiador e marxista convicto Eric Hobsbawn, em a Era dos extremos notou perspicazmente que

[...] as instituições da democracia liberal praticamente desaparecem entre $1917 \mathrm{e}$ 1942; restou apenas uma borda da Europa e partes da América do Norte e da Austrália. Enquanto isso, avançavam o fascismo e seu corolário de movimentos e regimes autoritários (HOBSBAWN, 1995, p.17).

No entanto, escapou na referência de Ferguson sobre a civilização ocidental que o principal conflito hoje é entre o Iluminismo e o Romantismo. Conflito que suscita a divisão central no Ocidente em dois blocos antagônicos. No presente contexto, um dos blocos do Ocidente pende para os rescaldos do tribalismo e o outro para os seus elementos singulares, como a cultura da liberdade, a sociedade aberta, a ciência, a filosofia, a democracia, o Estado de Direito, a tolerância, o individualismo e o livre mercado. Evidentemente, conforme sugere Isaiah Berlin, o Ocidente está assentado em dois polos opostos. De um lado, o velho Ocidente, do outro lado, o novo Ocidente. Enquanto o velho Ocidente relaciona-se com as sociedades tribais de caçadores-coletores organizadas desde as primeiras formas em torno do parentesco, o novo Ocidente é herdeiro da Grécia e que por meio da Renascença, da Revolução Científica, da Revolução Gloriosa, do Iluminismo e da Revolução Americana chegou aos dias de hoje. Afinal, o velho persiste por um bom tempo antes de morrer. É o novo Ocidente e tudo o que possui de inovador e de próspero que é visto pelos românticos como ameaça ao resto do mundo. O que preparou o caminho para ou aumento da sensibilidade e da consciencialização do lado mais insidioso e torpe da civilização ocidental. Em consequência da liberdade de crítica, o novo Ocidente sempre procurou retificar os erros do velho Ocidente. Porque a liberdade de crítica tornou a civilização ocidental automaticamente autocrítica. Por isso, a sociedade civilizada ocidental seguiu um curso muito peculiar e diferente do resto do mundo. Foram, inclusive, os traços críticos herdados da Grécia que tornou possível o combate a opressão, a intolerância, a escravidão, ao colonialismo, ao racismo, ao imperialismo, a homofobia e o sexismo. Em suma, foi a civilização ocidental que deu significado à liberdade, à igualdade e à justiça entre as pessoas.

Na verdade, os românticos retratam a concepção de sociedade "natural” perfeita lançada por Rousseau. E com a introdução de vários aperfeiçoamentos, em decorrência da alteração das circunstâncias. O ponto decisivo foi o de a revolução romântica levar a cabo um feroz ataque ao novo Ocidente. Assim, é adicionada ao protorromantismo de Rousseau a associação equivocada do novo Ocidente ao colonialismo, ao imperialismo, ao racismo, ao

\begin{tabular}{|l|l|l|l|l|}
\hline Q ovista Dialectus & Ano 10 & n. 22 & Edição Especial, junho 2021 & p. 237 - 255 \\
\hline
\end{tabular}


fascismo, ao eurocentrismo etc. A razão de tal ataque resulta em um paradoxo: o Ocidente em volta da violência e morte de milhões de seres humanos ou o Ocidente que permitiu à humanidade libertar-se do despotismo, do dogmatismo, da superstição e da ignorância. A divisão da civilização ocidental em duas, a velha e a nova, não pode ser negada e serve para mostrar o lado que existia muito antes do recém-saído do "milagre grego". Na verdade, os acontecimentos envolvidos no florescimento das maiores e espetaculares conquistas gregas em um pequeno espaço de tempo ainda carecem de uma resposta mais precisa. Isso é precisamente o que evoca o chamado "milagre grego". Algo que tende a ser muito mais uma anomalia que requer explicação. Bertrand Russell afirma que

O advento da civilização grega que produziu tal explosão de atividade intelectual é um dos acontecimentos mais espetaculares da história. Jamais ocorreu algo semelhante, nem antes nem depois. No curto espaço de dois séculos os gregos produziram na arte, na literatura, na ciência e na filosofia uma assombrosa torrente de obras primas que estabeleceram os padrões gerais da civilização ocidental (RUSSELL, 2001, p.13).

De modo análogo aos escritos de Berlin, o trabalho de Searle também ajuda a esclarecer o pano de fundo dessa disputa entre Iluminismo e Romantismo. A certa altura de sua carreira, Searle notou que o espírito crítico da civilização ocidental estava desaparecendo das universidades americanas. Por isso, assinala no ensaio Racionalidade e realismo: o que está em jogo?

Há décadas que assistimos, nas universidades americanas que se dedicam à investigação, a debates sobre a natureza do ensino superior. Controvérsias arrebatadas sobre o plano de estudos, sobre as exigências acadêmicas e mesmo sobre os objetivos do próprio ensino superior não são coisas novas. Mas os debates agora em curso são em certos aspectos invulgares. Ao contrário dos reformadores acadêmicos do passado, muitos dos que atualmente põem em causa a tradição acadêmica têm fins políticos explicitamente de esquerda e procuram atingir objetivos explícitos. Além disso, e o que é mais interessante, põem em causa muitas vezes não apenas o conteúdo do plano de estudos, mas as próprias concepções de racionalidade, verdade, objetividade e realidade que foram dadas como garantidas no ensino superior, tal como tem sido dadas como garantidas em geral na nossa civilização (SEARLE, 1999, p.3).

Ao fim e ao cabo, houve uma grande mudança nos valores e no pensamento político ocidental e que foi desencadeado pela revolução romântica, da qual fala Berlin. Em vez dos 
valores assentes na verdade e na liberdade, o Ocidente se viu invadido por outros inteiramente discordantes como:

integridade, sinceridade, disponibilidade para sacrificar a vida e para alguma chama interior, dedicação a algum ideal pelo qual valia a pena sacrificar tudo aquilo que a pessoa é, pelo qual valia a pena viver e também morrer (BERLIN, 2015, p.32).

A revolução romântica inspira-se na "Revolução Copernicana" sustentada por Immanuel Kant na filosofia. Afinal de contas, no livro Crítica da razão pura, pensou ter realizado uma revolução equivalente à de Nicolau Copérnico na astronomia. Ao longo da história da filosofia, os objetos ocupavam uma posição-chave na teoria do conhecimento. Segue que a mente humana e os objetos exteriores tinham uma existência independente. Portanto, a relação da mente humana com o mundo se dava em termos de uma ordem linear que ia do sujeito ao conhecimento dos objetos. Kant opôs-se a tal ordem linear e bem definida em que a natureza permanecia além da vida mental. A inclinação de Kant para o idealismo recusou-se a endossar o realismo externo de seus antecessores. Em consequência, o conhecimento passava a depender completamente da mediação da mente humana (Searle, 1999). Pouco surpreende, portanto, que os idealistas alemães subsequentes rejeitassem o mundo real. Com isso, o mundo exterior foi substituído pelo sistema cognitivo do sujeito. De modo que a "Revolução Copernicana" acabou por culminar no novo idealismo dos filósofos alemães. Uma vez radicalizado o idealismo kantiano, o mundo se tornou uma representação ou construção social.

Kant também fez uma distinção decisiva entre a consciência cognitiva e volitiva. Ainda que distintas, como pensava Kant, cognição e volição formavam uma unidade absoluta. Nesse contexto, o conhecimento é um produto da cognição e as ações da volição. Foi contra esta distinção que Fichte reagiu e depois se tornou o ponto comum de toda antifilosofia romântica. Na citação que Steven Pinker fez de Herder já se pode ver claramente a oposição entre a razão pura e a razão prática kantiana. Diz Herder: "Não estou aqui para pensar, mas para ser, sentir e viver" (PINKER, 2018, p.413).

O contraste entre o Romantismo e o Iluminismo é ainda mais profundo a partir de Fichte: "Nós não agimos porque sabemos, nós sabemos porque somos chamados a agir" (BERLIN, 2015, p.139). Fichte reivindica, por conseguinte, a primazia da razão prática sobre a razão pura. Berlin encontrou exatamente isso na seguinte declaração de Fichte. "A verdadeira natureza do homem não é a receptividade passiva - ócio, contemplação - mas atividade 
(BERLIN, 1999, p. 253). Desde então, devido a filosofia idealista de Fichte, um dos mestres ou pais do Romantismo, o conhecimento é resumido a ação.

A mesma primazia é reivindicada por Karl Marx na $11^{\mathrm{a}}$ tese sobre Feuerbach, onde escreve que "os filósofos somente interpretaram o mundo em vários sentidos; a questão é transformá-lo" (SINGER, 2003, p.52). A reviravolta operada por Marx no idealismo alemão está ligada ao fervor revolucionário e tinha muito em comum com a raiva sentida por Rousseau pela sociedade em que vivia. Ao contrário dos filósofos idealistas alemães, Marx é um materialista: as relações econômicas é que determinavam a vida social e não as especulações intermináveis dos filósofos. A filosofia de Marx tem, pois, finalidades políticas bem delimitadas. Na origem dessa filosofia política encontra-se o idealismo de Georg W. F. Hegel. A rigor, o seu materialismo é apenas o idealismo hegeliano virado pelo avesso (ou de cabeça para baixo). Em outras palavras, o materialismo de Marx não é genuíno e nem particularmente original por manter pouca distância do idealismo alemão.

Claro que para Fichte, Hegel e Marx, a vida social é essencialmente prática. Quando se fala do Fichte, um dos pais do Romantismo e do idealismo alemão, na última fase, desenvolveu forte afinidade com o nacionalismo cultural de Herder na medida em que se empenha em pensar os seres humanos nos termos de uma unidade orgânica. Em outras palavras, o "eu" que delibera e age no seio do mundo prático, se torna na filosofia de Fichte, uma entidade coletiva ou uma espécie de "supra indivíduo". Em $O$ sentido da realidade, Berlin expõe que, para Fichte, "O indivíduo não existe...ele não deveria contar para nada, devendo ao contrário, desaparecer completamente; só o grupo existe" (BERLIN, 1999, p.251). A obra de Hegel, por seu turno, vai ainda mais longe na inclinação pelo idealismo romântico, ao admitir que o indivíduo é secundário em relação ao Estado. A seguir, afetado por Fichte, e ao mesmo tempo fiel às preocupações teológicas sobre a natureza de Deus, Hegel invocará a noção de Espírito. E Hegel defende, com base em uma visão comunitária, que o Espírito é uma forma de consciência coletiva encontrada na arte, na religião e na filosofia. Com efeito, Hegel sugere que só o Espírito é real (BEISER, 2014). Outra particularidade que é preciso adicionar é a do constante desenvolvimento. Desse modo, sua concepção de Espírito traz à tona o interesse dos românticos pela história. A verdade é que Hegel acaba por descrever o curso da história do Ocidente como um movimento progressivo rumo a um destino final. $\mathrm{O}$ empenho em descobrir na história uma espécie de padrão ou leis, através das quais a mesma avança, leva Popper a qualificar Hegel de historicista (POPPER, 1987). Marx também procura oferecer, como Hegel,

Qevista Dialectus
Ano 10 n. 22

Edição Especial, junho 2021

p. $237-255$ 
um relato do curso da história bem próximo do cristianismo. Mais precisamente, conforme evidencia Berlin, o marxismo, de maneira semelhante ao cristianismo, abrange uma concepção da queda da humanidade, de seu sofrimento, redenção e posterior salvação final (Berlin, 2003). A atração do marxismo se deve muito à possibilidade do advento da sociedade sem classe (após o desaparecimento do capitalismo). Com muito boa razão, Paolo Rossi escreveu:

Hoje, se há algo que me parece que se possa ter certeza é o seguinte: o 'deslocamento' da teologia à história foi uma clamorosa e irremediável. Os paraísos futuros não só não se realizaram, mas aquele tipo de esperança deu origem a projetos não sensatos e que se tornaram praticáveis através do uso sistemático da violência. Acreditar que projetos sensatos e praticáveis possam nascer a partir de um 'deslocamento' da teologia a uma história (ou até mesmo a uma ciência da história) foi a perigosa, falimentar e sangrenta ilusão do século XX (ROSSI, p.8-9).

O historicismo de Hegel e Marx baseia-se em um conjunto de noções que se situa para além da esfera comum da filosofia da história. Diversamente também daquelas derivadas do Iluminismo e que aparece no entendimento da influente ideia de progresso. Por seu turno, Steven Pinker expõe de forma bem plausível esse descompasso no entendimento da ideia de progresso entre os iluministas e o presente no historicismo de Hegel e de Marx quando diz que:

Não devemos confundir a crença iluminista no progresso com a romântica crença oitocentista em forças, leis, dialéticas, lutas, desdobramentos, destinos, idades do homem e poderes evolucionários místicos que impeliriam a humanidade sempre para cima, em direção à utopia (PINKER, 2018, p.8).

Portanto, as duas tendências fundamentais da filosofia da educação que Suchodolski delineia em sua obra, A pedagogia e as grandes correntes filosóficas, embora brinde o campo com uma tentativa engenhosa, pesa sobre ela algumas reservas. A principal é a de não identificar a pedagogia da existência com a revolução romântica. Ou seja, Suchodolski deixou de juntar ao existencialismo, a filosofia idealista alemã. No seu livro Idealismo alemão, Will Dudley traça uma linha de demarcação bem direta que vai de Kant a Marx e do existencialismo ao pós-modernismo:

Kant, Fichte, Schelling e Hegel - os quatro mais importantes filósofos idealistas alemães - pavimentaram o caminho para Marx e Kierkegaard, a fenomenologia e o existencialismo, a teoria crítica e o pós-estruturalismo, e ao fazerem isso deixaram uma marca que permanece altamente visível na teoria social e política contemporânea, nos estudos religiosos e na estética (DUDLEY, 2013, p.13).

Isso significa que a análise de Berlin a respeito do verdadeiro herdeiro do Romantismo, por reportar tão somente ao existencialismo se demonstra incompleta. Mais 
perspicaz foi a resposta dada a pergunta de Ramin Jahanbegloo acerca da maior atração da filosofia francesa pela filosofia alemã do que pela filosofia inglesa:

A filosofia inglesa sempre foi atraída pela clareza do pensamento, pelo controle das teorias e das hipóteses, pela análise das significações por meios da experiência. Assim foi no tempo de Descartes e na realidade até o aparecimento de Bergson. Nos anos 30, em parte por causa da chegada à Paris de filósofos alemães refugiados, ela foi levada para os problemas existenciais e para os estilos de pensamento hegelianos e póshegelianos que Russell e Moore, efetivamente expulsaram da Inglaterra bem no começo deste século (JAHANGEBLOO, 1996, p.77).

Assim é encetado o grande antagonismo da filosofia contemporânea, de um lado, o mundo da fala inglesa, de outro lado, o mundo de fala franco-germânica. Richard Dawkins traça com extrema lucidez o resultado dessa oposição que Franca D’Agostini expôs no livro Analíticos e Continentais (D'AGOSTINI, 2003). De acordo com Dawkins:

Os filósofos falam despreocupadamente em 'filosofia continental' para contrastá-la com a 'filosofia analítica'. Departamentos de filosofia em universidades americanas ou britânicas podem até procurar candidatos para lecionar 'a tradição continental'. Dá para imaginar um departamento científico anunciando a abertura de uma vaga para um professor de 'química continental?' A própria ideia é uma piada de mau gosto. Isso já diz bastante sobre os valores da ciência e não enaltece os da filosofia (DAWKINS, 2018, p.19).

\section{CONSIDERAÇÕES FINAIS}

Para terminar, a contraposição entre filósofos continentais e filósofos analíticos ajuda a definir os desafios colocados à filosofia da educação. A referência de Suchodolski a filosofia da educação essencialista e a filosofia da educação existencialista (tratada por ele pela designação de pedagogia da essência e pedagogia da existência) correspondem na época atual a especificidade da filosofia da língua inglesa ou anglo americana e a filosofia de língua ou francesa e alemã ou franco-germânica. Todavia, diferentemente da filosofia continental, a filosofia analítica compreende uma tradição que tem influenciado o Ocidente desde os primeiros cientistas-filósofos gregos (POPPER, 2014). É o que John Searle também enxerga quando procura articular sua compreensão dessa tradição. Segundo Searle:

Há uma concepção da realidade e das relações entre realidade, por um lado, e o pensamento e a linguagem, por outro, que tem uma longa história na tradição intelectual ocidental. Na verdade, esta concepção é tão fundamental que em certa medida define essa tradição. Envolve uma concepção muito particular de verdade, razão, realidade, racionalidade, lógica conhecimento, justificação e demonstração.

\begin{tabular}{|l|l|l|l|l|}
\hline Qovista Dialectus & Ano 10 & n. 22 & Edição Especial, junho 2021 & p. 237 - 255
\end{tabular}


Sem exagerar muito, podemos descrever esta concepção como 'a metafísica ocidental'. A metafísica ocidental assume formas diferentes, mas subjaz à concepção ocidental de ciência, por exemplo. A maior parte dos cientistas em exercício tomamna pura e simplesmente como dada. Na concepção mais simples de ciência, o objetivo desta é alcançar um conjunto de frases verdadeiras, idealmente sob a forma de teorias precisas, frases essas que são verdadeiras porque correspondem, pelo menos aproximadamente, a realidade que tem uma existência independente (SEARLE, 1996, p.4).

No entanto, costuma ser um tanto esquecido entre os filósofos continentais que o ceticismo é tão velho quanto o essencialismo. Há mais de dois mil anos que o termo "cético" significa investigação criteriosa e com Sócrates passou a ser levada a cabo por meio da refutação, exame crítico ou discussão crítica (POPPER, 2013). Como aponta Searle,

a ideia de uma crítica consistiu sempre em submeter qualquer crença aos mais rigorosos padrões de racionalidade, justificação e verdade. Sócrates é o herói do ramo intelectual da tradição metafísica ocidental em grande parte porque nada aceitava sem discussão e porque era implacavelmente crítico relativamente a quaisquer tentativas de resolução dos problemas filosóficos. (SEARLE, 1999, p.5).

Nas mãos de Aristóteles a refutação, o exame crítico ou discussão crítica é abandonado. A investigação voltada para a busca da verdade passa a estar atrelada ao método indutivo. René Descartes, em vez disso, utilizou o método dedutivo. Não obstante a diferença nos procedimentos metodológicos assinalados por Aristóteles e Descartes, dois dos maiores pensadores da ciência e da filosofia, são indubitavelmente essencialistas. Ora, é significativo notar que os filósofos herdeiros do essencialismo pretendem descrever os fundamentos do mundo recorrendo a uma explicação final ou explicação última porque descura de qualquer explicação posterior (POPPER, 1980). A filosofia tipicamente essencialista vingou até bem recentemente. Na cronologia de Suchodolski, a filosofia essencialista acabou sendo sucedida pela filosofia existencialista. O ponto crucial e que leva a um afastamento da perspectiva tomada por Suchodolski consiste na inclusão da filosofia da educação identificada com o marxismo e o pós-modernismo. O pressuposto filosófico do marxismo é o historicismo de Hegel e que chama a atenção para uma sucessão de estágios evolutivos percorridos pela humanidade. Marx também compartilhou da mesma convicção cientificista dos positivistas. Cientificismo no seu zelo em apoiar o socialismo em uma teoria econômica (McLELLAN, 1975). Consequentemente, o seu socialismo seria o único científico. Uma vez frustradas as pretensões científicas do marxismo, as inspirações morais ganharam preponderância. Para Ernest Gellner: 
A intuição moral que subjaz à ideia de socialismo e em particular ao marxismo é simples: a ganância, a obsessão de adquirir, a propriedade competitiva, a posse como status e principal símbolo da realização humana - tudo isso é mau. Não apenas mau; é também perfeitamente evitável: a propriedade e a competição econômica não estão escritas na natureza das coisas ou enraizadas no caráter humano. Pelo contrário são incompatíveis com a verdadeira essência da humanidade: os homens que se deixam dominar pela obsessão da aquisição individual e da posse se alienam da sua própria e verdadeira natureza. A absolutização da ganância é uma lei de falsa consciência imposta por uma ordem social temporária e patológica, que tenta proteger-se e fortificar-se por meio dessa falsidade, generalizando e tratando como intrínseca a sua própria visão distorcida do homem, historicamente específica; mas a verdade da humanidade reside no trabalho espontâneo e na cooperação (GELLNER, 1996, p.131).

Em última análise, a visão privilegiada acerca dos propósitos finais da história, tal como pregava o socialismo científico de Marx, mostrara-se falha. A tão proclamada onisciência revolucionária terminara nos episódios infelizes do regime totalitário de Josef Stalin. Questão de suma importância aos olhos dos marxistas e isso significou preservar o que dava do sistema teórico e ignorar o resto. Dispensado a parte científica, a atenção voltou-se para a voga da prática emancipadora. Na visão de Terry Eagleton:

Este tipo especial de teoria orientada para a ação é às vezes chamado de 'conhecimento emancipador', e tem alguns atributos distintivos [...] portanto, temos aqui uma forma peculiar de cognição em que o ato de conhecer altera aquilo a que se refere (EAGLETON, 1999, p.8).

Para dizer em uma palavra, os pós-modernistas são antirrealistas. Isso leva os pósmodernistas a rejeitarem a noção de realidade com existência independente, por compartilharem do perspectivismo de Friedrich Nietzsche. Com Nietzsche veio à tona a fórmula de que não há fatos, somente interpretações (Blackburn, 2006). O antirrealismo possibilitou, então, que o relativismo fosse professado na comunidade científica por meio dos defensores do construtivismo social. Logo, sem a necessária conexão entre a prática da investigação científica e a busca da verdade, a aceitação de uma teoria seria produto da retórica ou da negociação política. O conhecimento científico é reduzido a nada mais do que uma construção social. Os exageros do movimento pós-modernista foram amplamente denunciados no artigo intitulo Transgredindo as fronteiras: rumo a uma hermenêutica transformadora da gravidade quântica do físico Alan Sokal (SOKAL; BRICMONT, 1999). Apesar disso, a filosofia da educação 
continua a refletir as pressuposições relativistas do movimento pós-modernista. Como sugere Popper,

A principal enfermidade filosófica de nosso tempo é um relativismo intelectual e moral, baseando-se este último no primeiro, pelo menos em parte. Por relativismo ou ceticismo, se o leitor preferir - entendo aqui, em suma, a teoria de que a escolha entre teorias concorrentes é arbitrária; pois ou não há verdade objetiva ou que, de qualquer modo (embora talvez não verdadeira) chegue mais perto da verdade do que outra teoria; ou ainda, se houver duas ou mais teorias, não há modos nem meios de decidir se uma delas é melhor do que outra. (POPPER, 1987, p.389) .

As conclusões relativistas a respeito da epistemologia têm muito a ver com a afirmação dos pós-modernistas de que a ciência é meramente um instrumento de poder. Daí decorre que haveria por toda parte do Ocidente as mais pérfidas formas de dominação. De igual maneira, se a verdade não vem ao caso, somente as narrativas importam. A persuasão toma assim, o lugar da refutação, do exame crítico ou da discussão crítica. De modo que o radicalismo político pode tomar de assalto a filosofia acadêmica. Tal é o diagnóstico de Roger Kimball no livro Radicais nas universidades: como a política corrompeu o ensino superior nos Estados Unidos da América (KIMBALL, 2009).

Portanto, as implicações da filosofia sobre a prática educacional antecedem os dias de hoje. Desde a Grécia antiga, a filosofia tem deixado a sua marca no processo educacional. Antes mesmo de fazer parte de uma disciplina acadêmica autônoma, o modo de pensar crítico da filosofia se instalara na sociedade civilizada grega. Na democracia ateniense, Sócrates, como filósofo e professor alterava práticas de ensino consolidadas. Não por acaso, através da investigação colaborativa, ajudava os atenienses a pensarem criticamente. Evidentemente, a filosofia passava a atender a um tipo de finalidade educacional com implicações diretas na sociedade. O ponto importante a ser destacado é o de que a filosofia da educação, no decurso de sua história, procurou dar respostas aos problemas concernentes à natureza do processo educacional, à finalidade que pretende realizar e ao exame crítico das teorias do campo. A investigação colaborativa conduzida por Sócrates é semelhante à que fincou raízes na ciência. $\mathrm{Na}$ filosofia e na ciência, a refutação, ou o elenchos socrático, mantem-se atual. Por conseguinte, o modo de pensar crítico continua sendo de fundamental importância para a civilização ocidental. A filosofia da educação, em especial, adquire especial relevância no momento atual em que a insatisfação com o Ocidente passou a constituir uma ameaça à própria democracia e à cultura da liberdade que a diferencia de qualquer outro lugar. Mais

\begin{tabular}{|l|l|l|l|l|}
\hline Rovista Dialectus & Ano 10 & n. 22 & Edição Especial, junho 2021 & p. 237 - 255
\end{tabular}


especificamente, isso quer dizer que se faz necessário reacender o espírito crítico das Luzes. E o relativismo generalizado é o maior adversário dessa retomada. A isso se soma a adoção de uma filosofia da educação de espírito igualmente iluminista, para que a época atual afaste a ameaça do relativismo e se torne, realmente, esclarecida.

\section{Referências}

BAISER, Frederick. Hegel. São Paulo, Ideias \& Letras, 2014.

BERLIN, Isaiah. Karl Marx. Madrid, Alianza Editorial, 2003.

BERLIN, Isaiah. As Raízes do Romantismo. São Paulo, Ed. Três Estrelas, 2015.

BLACKBURN, Blackburn. Verdade: Um Guia para os Perplexos. Rio de Janeiro, Ed. Civilização Brasileira, 2006.

OZMON, Howard A.; CRAVER, Samuel, M. Fundamentos Filosóficos da Educação. Porto Alegre, Ed. Artmed, 2004.

D’AGOSTINI, Franca. Analíticos e Continentais. São Leopoldo, Ed. Unisinos, 2003.

DAWKINS, Richard. Ciência na Alma. São Paulo, Companhia das Letras, 2018.

DUDLEY, Will. Idealismo Alemão. Petrópolis, Vozes, 2013.

EAGLETON, Terry. Marx. São Paulo, Editora Unesp, 1999.

ELIADE, Mircea. Mito e Realidade. São Paulo, Perspectiva, Petrópolis, Vozes, 1986.

FERGUSON, Niall. Civilização: Ocidente x Oriente. São Paulo, Ed. Planeta, 2012.

FULLAT, Octavi. Filosofias da Educação. São Paulo, Ed. Vozes, 1995.

GARDNER, Howard. Mentes que Mudam. Porto Alegre, Artmed, 2005.

GELLNER, Ernest. Condições da Liberdade. Rio de Janeiro, Jorge Zahar Editor, 1996.

GRAY, John. Cachorros de Palha. Rio de Janeiro, Ed. Record, 2007, p.71.

HOBSBAWM, Eric. Era dos Extremos: o breve século XX. São Paulo, Companhia das Letras, 1995.

JAHANGEBLOO, Ramin. Isaiah Berlin: Com Toda Liberdade. São Paulo, Editora Perspectiva, 1996.

KANT, Immanuel. Crítica da Razão Pura. Lisboa, Ed. Fundação Calouste Gulbenkian, 1994.

\begin{tabular}{|c|c|c|c|}
\hline Qevista Dialectus & Ano 10 & n. 22 & Edição Especial, junho 2021 \\
\hline
\end{tabular}


KIMBALL, Roger. Radicais nas Universidades: como a política corrompeu o ensino superior nos Estados Unidos da América, São Paulo, Editora Peixoto Neto, 2009.

LIPPMAN, Matthew. O Pensar na Educação. Petrópolis, Vozes, 1995.

LAUDAN, Larry. O Progresso e seus Problemas. São Paulo, Editora Unesp, 2011.

McLELlAN, David. As Ideias de Marx. São Paulo, Cultrix, 1975.

MIALARET, Gaston. Ciências da Educação. São Paulo, Martins Fontes, 2013.

MILL, John S. Sobre a Liberdade. Campinas, Vide Editorial, 2018.

OZMON, Howard A.; CRAVER, Samuel M. Fundamentos Filosóficos da Educação. 6 a ed. Porto Alegre: Artmed, 2004.

PINKER, Steven. O Novo Iluminismo. São Paulo, Ed. Companhia das Letras, 2018.

POPPER, Karl. Conhecimento Objetivo. Belo Horizonte, Editora Itatiaia; São Paulo, EDUSP, 1975.

POPPER, Karl. A Lógica da Investigação Científica. São Paulo, Abril Cultural, 1980.

POPPER, Karl R. O Mito da Estrutura. In Documentação e atualidade, nº11, julho, 1980, p.70.

POPPER, Karl. A Sociedade Aberta e Seus Inimigos. Belo Horizonte, Editora Itatiaia; São Paulo, EDUSP, vol.2, 1987.

ROSSI, Paolo. Esperanças. São Paulo, Ed. Unesp, 2013.

RUSSELL, Bertrand. História do pensamento filosófico: a aventura das ideias - Dos présocráticos a Wittgenstein. Ediouro, Rio de Janeiro, 2001.

SEARLE, John. Racionalidade e Realismo: o que está em jogo? In Disputatio 7, novembro, 1999, p.6.

SINGER, Peter. Marx. São Paulo, Edições Loyola, 2003.

SUCHODOLSKI, Badan. A Pedagogia e as Grandes Correntes Filosóficas. Ed. Livros Horizonte, 5.a ed., 2000.

ZIMAN, John. Conhecimento Público, Belo Horizonte, Editora Itatiaia; São Paulo, EDUSP, 1982. 